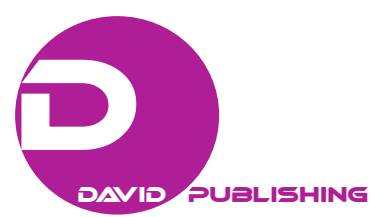

\title{
The Case of the Aryan Jesus Dogma: Enlarging Entitlement Through Propaganda
}

\author{
Paul Wilson \\ Shaw University, North Carolina, United States
}

\begin{abstract}
In a national effort to promote anti-Semitism, the Institute for the Study and Eradication of Jewish Influence (ISEJI) was established in Nazi Germany. Its leader, Walter Grundmann, was instrumental in the promotion of the Aryan Jesus dogma in scholarly circles. Through a quid pro quo arrangement with a state-based university, the dogma was given scholarly respectability. The dogma asserted that Jesus was not Jew. This dogma gained enough support to be adopted into the German Lutheran Church's catechism of the time. Not only was the motivation for the promotion of the dogma suspect, but the reasoning used to arrive at the conclusion was faulty. The dogma contributed to the body of Nazi propaganda that vilified Jews as enemies of the Aryan society.
\end{abstract}

Keywords: Nazis, anti-Semitism, Aryan, propaganda, genocide

The creation and deployment of a "kill-switch" to activate a sleeper agent is the stuff of Cold War spy novels. It is also a fair description of how some international powers in the 20th century did manipulate their covert agents to act as killers. An enemy would recruit a citizen to become a member of an elite society; welcome the intended agent into its ranks; and program the intended agent using behavioral conditioning, hypnosis, or mind altering drugs. Then, the enemy would plant its agents within the targeted society to await further instruction. The successfully conditioned recruit would respond on cue to a subtle, subliminal message. At any moment, the kill-switch message would activate the recruit to execute the will of the enemy.

Without apology, the Nazis deployed a subtle, subliminal message borrowed from German theologians: Jesus was no Jew; Jesus was an Aryan. Throughout this study, the phrase-Jesus was an Aryan—and the carefully crafted story that supported it shall be called the Aryan Jesus dogma. On the one hand, to claim that the phrase was a kill-switch would be an overstatement. On the other hand, to ignore the power of the phrase to influence the action of German soldiers and the public during the holocaust would be a gross oversight. This author supposes the dogma functioned as one of a series of sufficient causes that would entice German police or citizens to murder innocent Jews without remorse. In other words, the Aryan Jesus dogma proved to be causally efficacious in the decision of individuals to kill or not kill Jews. Why and how the dogma was developed are larger questions for not only religious scholars and ethicists but also historians. This study shall focus upon the fallacious argumentation of the main claims of the Aryan Jesus dogma.

Paul Wilson, Ph.D., professor, Division of Social Sciences, Religious Studies, and the Arts, Shaw University, North Carolina, United States. 


\section{Introduction}

The Aryan Jesus dogma was an important part of the propaganda the Nazis would use. Upper ranking Nazis officials were fully committed to a racist ideology that would justify the mistreatment and killing of Jews. Many soldiers and German citizens already internalized the anti-Semitism prevalent in 20th century Europe when the Nazis ruled. Hitler (1943) made a veiled appeal to ancient animosities against the Jews, when he claimed that the Jews were responsible for the loss of World War I and the depression. Great masses of Germans accepted his views uncritically. The Nazi leaders were intent on the transformation of soldiers and German citizens into Jew killers as a final solution.

In spite of these persuasive forces, individuals were not inclined to mistreat Jews without reason. Greater incentives would be required to motivate Germans to disrespect the basic dignity of another human and to take that person's life. While Germany's state supported churches could have provided the last line of defense in maintaining a civil society, the majority of German churches were supportive of the Nazification of the state. Traditionally, Christians were taught that the Christ whom they worshiped was a Jew, and this tradition could have provided at least one additional reason to respect the dignity of Jews as fellow humans.

Elsewhere the author has discussed how vast numbers of victims in the holocaust were killed at close range by bullet fire or bludgeoning. Soldiers, police, and civilians pulled the trigger to kill the Jews who would fill mass graves. Christopher Browning's (1993) work, Ordinary Men, chronicled the reports of men who were reluctant to make their first kill of Jews. The Ayran Jesus dogma removed a reason to respect Jews, while it reinforced the racial divide between Germans and Jews. Consequently, German citizens had one less reason to refrain from violence as a means to resolve ancient animosities against the Jews. In retrospect, it appears that German theologians who came to the defense of the notion that Jesus was an Aryan served the Nazis well.

\section{The Religious Appeal of an Aryan Jesus}

Religion is a powerful tool for any political entity to use to ground its ideology. When the NSDAP, that is, the Nazis first came to dominate German politics the party both needed and sought a religious foundation to add credibility to its plans. Although some scholars had contributed to the Aryan Jesus dogma prior to 1933, it was not articulated as a complete doctrine by the time the NSDAP had come to dominate German politics. It would require additional scholarly work to shape the dogma into a serviceable form. So, one may wonder why the Nazis did not turn to a readily available religion to ground their agenda.

The Nazis could have called upon other religions to validate the anti-Semitism of their ideology. One obvious choice from Germany's cultural origins was paganism. Some paganists were prepared to promote it as the state religion of choice. Erich Ludendorf was reputed to be the first paganist in the Nazi movement. Ironically Ludendorf was the only paganist expelled from the Nazi party (Steigman-Gail, 2003, p. 112). The composer Richard Wagner identified Christ with the pagan deity Wotan (Steigman-Gail, 2003, p. 101). One of Hitler's leading officers, Heinrich Himmler, was a paganist. The most outspoken paganist in the Nazi party was Alfred Rosenberg, but his writings led only to subtle reforms of German citizens' theological views rather than outright conversions to paganism (Heschel, 2008, p. 203).

In spite of its ready advocates, the German population only marginally embraced paganism. For the most part, Germany in the 20th century ignored its ties to paganism and identified itself as a Christian nation. Matthew D. Hockenos (2004) observed, "In 1933 approximately 41 million Germans were officially registered 
as Evangelical (Protestant) and 21 million as Catholic from a population of 65 million” (p. 4). That amounts to $97 \%$ of Germans who were reported to be Christians. While a significant part of that population was Catholics, the majority of Germany's Christians proudly identified themselves with the protestant religion of the famed reformer Martin Luther. It is not surprising that Germans in the 20th century would flout Luther's anti-Semitism as a defense of their own anti-Semitism. The ancient animosities within German society channeled hatred of the general population against Jews.

In 1933, the majority of Germany's citizens may have been viewed nominally as Christians, but they were by no means united in their beliefs. Among those calling themselves Christians were Roman Catholics and numerous Protestants. Given their allegiance to the order of the Catholic Church, Catholics' loyalty to Hitler and the Nazis would remain in question. The remaining Protestant population became sharply divided when pastors and churchgoers began to question the direction of the Nazis. In the Protestant population, the German Christian movement, that is, the DS Church consisted of about 600,000 persons who supported the Nazis. They were in agreement with the terms of the “Aryan paragraph” (Hockenos, 2004, p. 214). The so-called Aryan paragraph was a state supported policy intended to remove from service pastors who were not full-blooded Aryans, that is, pastors who had Jewish ancestors.

The Confessing Church was comprised of a much smaller segment of Germans who identified themselves as Christians. Hockenos (2004) said,

Of the 18,000 Protest pastors in Germany, fewer than one-third were adherents of the German Christian movement. Although the number of pastors who joined the Confessing Church reached just over 7,000 in January 1934, for most of the period from 1933 to 1945 the number was fewer than 5,000. (p. 6)

Notable persons in their ranks included Martin Niemoller and Dietrich Bonhoeffer. Members of the Confessing Church did not present a united front in opposing the anti-Semitic policies in the Aryan paragraph. Some opposed the practices demanded by the Aryan paragraph, while others were willing to enforce the prohibition against the service of pastors with Jewish ancestry. A few even agreed with the Nazis that all sacraments of the church should be withheld from Jews.

During the early years of his ascendency to power, Hitler presented himself as a Christian. This common religious ground provided another way that the people of Germany could identify with their leader. Heinrich Himmler was one of the most powerful men in Hitler's inner circle and was a paganist. While Hitler trusted Himmler as head of the police division, he rejected Himmler's paganism calling it a "chimera”. In a 1937 entry in Joseph Gobbels diary, it was said that Hitler found in Christ his inspiration to fight the Jews (Steigman-Gail, 2003, p. 154). Of course, Hitler's inspiration was the Aryan Jesus who was a strong spirited person of Aryan blood whose enemies were the Jews.

\section{The Theological Support of an Aryan Jesus}

To say that the Nazi war on Jews was a war on all fronts is an understatement. So, committed to anti-Semitic policies and procedures were the Nazis that they sanctioned the opening of "The Institute for the Study and Eradication of Jewish Influence” (ISEJI) on May 6, 1939. Located in Eisenach, it was a short 87 miles away from the University of Jena. Ever prepared to seize upon the symbolism of the moment the opening was attended by Protestant pastors, theologians, and churchgoers at Wartburg Castle, the place where Martin Luther posted his 95 theses against Catholicism. By establishing the institute, the Nazis were taking one more 
step to wage ideological warfare against their religious enemy, Judaism. Walter Grundmann was appointed to serve as the head of the ISEJI, and he held a faculty appointment at the University of Jena (Heschel, 2008, p. 189).

Suzzanna Heschel (2008) observed that the University of Jena acted as an academic clearinghouse for members of the ISEJI. The university had the ability to confer terminal degrees upon members of the ISEJI. The ISEJI could reciprocate by providing students a place to display their scholarly work at conferences and through publications. Heschel (2008) said, "Several members of the Institute were able to receive doctorates at Jena, and the Institute offered significant assistance by publishing many of the dissertations by Jena students and offering them an opportunity to present their research at Institute conferences” (p. 201). In hindsight, these quid pro quo arrangements appear to make a mockery of academic scholarship, but at the time, these arrangements allowed theologians to validate the dogma under investigation.

Graduate students studying for their terminal degree know the horror stories of peers whose dissertations were rejected. At the University Jena, the deciding factor in gaining approval for a dissertation was often the willingness of the candidate to validate conclusions consistent with National Socialism. In other words, dissertation committee members were overtly seeking to validate anti-Semitism. Thus, the institute along with the theological school became a self-affirming propaganda machine. Working together they could produce propaganda that would align with the Nazi media campaign against the Jews. Candidates for terminal degrees were expected to demonstrate more than an affiliation with the NSDAP. They were expected to arrive at conclusions that were decidedly anti-Semitic. Eberhard Zetzel's dissertation was rejected for its failure to conclude that Judaism was spiritually unproductive. The committee rejected Wilhelm Richert's dissertation even after it was rewritten to respond to recommendations. Speaking of Richert's revised dissertation, Professor Wolf Meyer-Erlach said, "The theologian lacks the necessary understanding of National Socialism, that the racial question is the foundational question for everything...” (Heschel, 2008, p. 237).

Through its anti-Semitic publications, the ISEJI aimed at both the dejudaization of Christianity and its Nazification. An example of its dejudaization efforts was the removal approximately 350 hymns from the traditional German hymnal. The hymns were deemed unsuitable for worship due to their references to the Old Testament (Heschel, 2008, p. 118). At the direction of the institute hymns were removed or rewritten, biblical texts were subjected to critical revision, and the message of the catechism of the church was rewritten. Grundemann would later produce a life of Christ that was acceptable to the party.

Gerhard Kittle was one of several prominent German theologians active at this time. One of his most notable editorial works was the Theological Dictionary of the New Testament. Despite his prominence as a theologian, Kittle had to stand trial after the war for crimes against humanity. Some Jews testified in his defense that they had received his assistance. Their testimony could not obliterate an obvious change in Kittle's writings and speeches about Jews after 1933. Before the Nazis came to power Kittle allowed for the likelihood that non-Semitic blood could be found in Jesus' ancestry. In a 1926 publication, Kittle said, "It is conceivable that Jesus, if he was Galilean, had a couple of drops of non-Jewish blood in his veins” (Erickson, 1999, p. 52). Kittle's seemingly benign anti-Semitism was transformed into a vitrolic anti-Semitism. The post-war trial examined not only his theological writing but also his public speeches and writings. In his 1933 speech, "De Judenfrage”, Kittle spoke openly of the Jewish problem. He supposed there were only four possible solutions to the Jewish problem. They were: (1) extermination; (2) Zionism; (3) assimilation; or (4) guest status (Erickson, 1999, p. 55). Kittle rejected extermination on practical grounds, that is, attempts to exterminate a population 
had not been successful before.

Kittle's description of the Jewish problem epitomizes an underlying transformation of values. Though he rejected extermination as a practical option, the fact remains that Kittle entertained extermination as a possible option to solve the problem. Inclusion in the list is more than an indication of his deep-seated anti-Semitism. It is an affirmation of Kittle's commitment to the Nazi's view of superiority of the Aryan race. The problem supposes that preservation of the Aryan race has intrinsic value, while Jewish lives have negative instrumental value. Hence, the presence of Jews in Germany posed a problem to the preservation of the Aryan race.

\section{An Aryan Jesus Creed Reconstructed}

In retrospect, the Aryan Jesus dogma may appear as the product of a seamless, closely woven argument. In some sense, that falsifies the case. The dogma was constructed piecemeal, and religious and political leaders would have communicated it piecemeal to the public. Individuals familiar with the workings of scholarship understand that conclusions may emerge intermittently and may result in the retracing of previous steps and thoughts. Scholars and theologians at the institute would develop a piece of the theory, present it to their peers, and await the appropriate approval thereof. For instance, in 1908, Paul Haupt, a professor at Johns Hopkins University argued in print that Jesus was not born in Bethlehem of Judea (Heschel, 2008, p. 57). Members of the ISEJI assimilated this assertion along with others to disassociate Jesus with Judaism. As late as 1939, other theologians were still perfecting the argument that Jesus was not Jewish. The utility of the proposal for eliminating Jesus' ties to Judaism was tremendous. Once that hypothesis was accepted as dogma, it would then be disseminated as widely as possible through print and media to reach the general population. Pastors affiliated with the institute could resort to the pulpit to disseminate anti-Semitic ideas developed in the institute. Individuals already harboring anti-Semitic sympathies would receive without question the pronouncements of state sanctioned theologians that could possibly support the dogma.

The institute embraced its mission to de-Judaize Christianly. Its leaders rejected the Old Testament, and they aimed to produce a New Testament free of Jewish references and associations. Grundmann contributed a life of Christ that portrayed Jesus as an Aryan (Heschel, 2008, p. 152). Leaders of the institute sought to produce a hymnal that was free of references to Judaism. The institute's leaders even prescribed how and when Aryans were to pray.

By the year 1933, the endorsement of the Aryan Jesus view was already sufficiently advanced so that it could be introduced as part of the catechism of the state church (Ericksen, 1999, p. 53). That is to say, in the 1933 catechism of the German DS church, initiates were instructed that Jesus was not Jewish, but Jesus was Aryan.

By the end of the war, the ISEJI was dismantled and the denazification of the German society and church had begun, but by then scholars had already disseminated the Aryan Jesus dogma. If the process of Nazifying the church had continued uninterrupted after 1945, one may imagine that the German church would have developed a creed to affirm the Aryan Jesus dogma. What follows is an imaginary creed incorporating some of the elements that German theologians were asserting:

I believe in Jesus, born of Gentile parents in the northern capital of Bethlehem. I believe Jesus was a true prophet sent from God. I believe Jesus called himself the Son of Man in solidarity with all true Aryans. I believe Jesus' worst enemies were the Jews. I believe that Jesus came to bring a sword upon the earth to destroy the Jews in demonstration of his manly spirit. I believe Jesus' betrayer was a Jew from Jerusalem named Judas. I believe jealousy drove the Jews to kill Jesus. 
This imaginary creed brings together no less than seven positive assertions German theologians were prepared to make in support of the Aryan Jesus dogma. The ISEJI and the faculty of the University of Jena embraced the anti-Semitic assertions made prior to 1933 and added their own support to further the dogma. These assertions about Jesus are: (1) Jesus' gentile parentage; (2) Jesus' birth in gentile territory; (3) Jesus' opposition by Jews; (4) Jesus' refusal to assume the title of Jewish Messiah; (5) Jesus' strong and manly opposition to Jews; (6) the Jews' jealousy of Jesus; and (7) Jesus' betrayal and murder by Jews. The imaginary creed of the Aryan Jesus would raise a number of questions that German theologians were prepared to answer in their own way. We may now examine each assertion.

First, it was asserted that Jesus was born of gentile parentage. In 1896, the German Biblical scholar Ernest Renan published a Life of Christ. Renan (1910) said, "Jesus sprang from the ranks of the people. His father Joseph and his mother Mary were of humble station, living by their toil, workpeople in that condition so common in the East...” (p. 93). In this passage, Renan does not definitively identify Jesus' parents as gentiles, though he does say, "The population of Galilee, as the name itself indicates, was mixed". Renan openly admitted he aimed to eliminate the miraculous element from the account of Jesus' life. The assertion that Renan and other scholars made was that many persons repatriating Galilee in the Second Temple period were gentiles. If one assumes that many person repatriating Galilee were gentiles, one could infer only that some were gentiles and others were not. It does not follow that Jesus was the offspring of gentiles. Only if one were willing to say all persons born in Galilee were persons of Aryan blood would the conclusion follow, but that would commit the informal fallacy of composition.

Second, it was asserted that Jesus was either born in Nazareth or that he was not born in Bethlehem of Judea. Renan asserted that Jesus was born in Nazareth, and he claimed the tradition of Jesus' birth in Bethlehem arises from a corruption of an Old Testament text. In 1908, Paul Haupt of Johns Hopkins University attempted to explain away the Bethlehem tradition with a novel suggestion. He argued that there was a second Bethlehem that served as the capital of the province of Galilee (Heschel, 2008, p. 153). In his later article, "The Crib of Christ”, he concluded, “Jesus who was not a son of David, was born at Nazareth” (Haupt, 1920, p. 159). The explanations of Renan and Haupt both appear to be conjectures, given the textual evidence of Luke's birth account and supporting texts to the contrary.

Third, it was asserted that Jesus' enemies were the Jews. The Gospel of John includes several dialogues Jesus had with Jewish leaders. In John 8:44, Jesus replies to the Jews in Jerusalem who are touting their Abrahamic descent. To them, Jesus said, "You belong to your father, the devil, and you want to carry out your father's desire. He was a murderer from the beginning...”. In Hitler's thinking, this quotable line provided evidence that the Jews were sub-human. In his book, Mein Kaumf, Hitler (1943) said, "In defending myself against the Jews, I am fighting for the work of the Lord” (p. 65). That Jesus had enemies and that many of them were Jews are undeniable. However, this assertion makes use of the same fallacious reasoning as the first assertion. Some Pharisees were Jesus' enemies, some Sadducees were Jesus enemies, and the high priests proved to be enemies of Jesus. Having demonstrated that part of the Jewish people were enemies of Jesus, one cannot conclude the all Jewish people were enemies of Jesus. The household of Mary, Martha, and Lazarus were friends of Jesus. The Jewish ruler Nicodemus was a supporter of Jesus. One must indulge in a fallacy of composition to assert that finding some enemies of Jesus within the Jewish people was evidence that all members of the Jewish people were his enemies. 
Fourth, it was asserted that Jesus took up the title of Son of Man to avoid identification as the Messiah. Honorific titles for Jesus were not problematic for Nazis, if the titles did not infer that Jesus was the Messiah. The Gospel of Mark most frequently used the title, the Son of Man, to identify Jesus. When Jesus uses the title in Mark 8:38 or Mark 13:26, it is used as an oblique self-reference. In both instances, the title is used in describing apocalyptic events, and the title has Messianic connotations. The textual evidence clearly favors the messianic connection. Renan readily acknowledged the connection. He said, "The application made of [the Son of Man] by Jesus to himself, accordingly, proclaims his messiahship (1910, p. 173). To disassociate Jesus' self-reference with the office of the Messiah, the scholar Paul Haupt resorted to an appeal to authority that aims to ignore the textual evidence.

Wellhausen says he agrees with Eerdmans, of Leyden, and Lietzmann of Jena, in denying that Jesus called himself the Son of Man. This does not mean that Jesus did not use the phrase for the pronoun of the first person, but that he did not employ the term to designate himself as the Messiah. (1919, p. 133)

Fifth, it was asserted that Jesus offered a strong and manly opposition to the Jews. It was Jesus' manly strength that appealed to Hitler (Steigman-Gail, 2003, p. 154). Yes, Jesus fought Jews. Here, the problem of quantification appears again. Jesus fought Jews. Did he fight some Jews? Yes. Did he fight many Jews? Perhaps. He did fight the numerous leaders of organized religion of his day. Did he fight all Jews? No. His own disciples included Jews from both Judea and Galilee.

Sixth, it was asserted that Jesus' betrayer was a jealous Jew-Judas, a Jew from Jerusalem. Tradition does indicate that Judas was from Judea, while the majority of the disciples were from Galilee (Kerr, 1939). However, the ethnicity of the remaining disciples was not Aryan. Peter was a dedicated Jew whose commitment to ceremonial laws proved to be an obstacle in the life of the early church. Another disciple, Simon Zealotes was a member of the radical Zionist faction of Jesus' time. In addition, the disciple John seems to have had family ties with the high priest. Jesus did have an enemy in Judas, but he was not the only enemy Jesus had. Neither was Judas the only disciple of Jesus who was a Jew.

Seventh, it was asserted that Jews killed Jesus. This supposed assertion illustrates how innuendos were deployed to vilify Jews. Jewish leaders met in the night to prepare Jesus' prosecution. They could not legally convene a trial until sunup, and then their ritual observations of the Passover hampered their proceedings. When the Jewish court condemned Jesus, they appealed to Pilate to have Jesus executed. It was undeniable that Jews were complicitous in the death of Jesus and that they had pronounced a death sentence upon Jesus. However, it was the Roman guard that crucified Jesus. The supposed assertion that Jews killed Jesus overlooks the fact that the executioners of Jesus' death sentence were Roman soldiers who were under the command of Pilate. In his book, The Christ of the Gospels, Shepherd (1939) said,

Sometime between six and nine o'clock the final sentence was pronounced by Pilate and Jesus was turned over to the Roman soldiers to be crucified. These soldiers of the governor belonged to a cohort made up of Syrians, or more probably Germans. (p. 593)

How was this innuendo about the killing of Jesus turned against the Jews? Hitler (1943) drew on the latent anti-Semitism in Germany to declare that Jews were violent and untrustworthy (p. 325). Propagandists like Julius Striker used his newsletter, Der Sturmer, to promote the idea that Jews were guilty of ritual murder (Bergen, 2016, p. 55). John 19:16 says simply, "Finally Pilate handed him [Jesus] over to them to be crucified”. If someone were already predisposed to condemn Jews as murderers, the text could be wielded to support their 
supposition. To illustrate how this ambiguity could be turned into an indictment of Jews, it considers the statement of Alfred Edersheim in The Life and Times of Jesus the Messiah.

It matters little as regards their guilt, whether pressing the language of St. John, we are to understand that Pilate delivered Jesus to the Jews to be crucified, or, as we rather infer, to his own solders.... We can scarcely imagine that the Jews, still less the Sanhedrists, would have done this. But whether formally or not, the terrible crime of slaying, with wicked hands, their Messiah King rests, alas, on Israel. (Edersheim, 1971, Part 2, p. 582)

The imaginary Aryan Jesus creed brings together many of the assertions and innuendos that Nazis made about Jesus of Nazareth. The imaginary creed unites the piecemeal assertions that Nazis did defend in support of the dogma. Those who defended the dogma made full use of the aura of respectable scholarship. However, the cloak of scholarship cannot overcome the lack of textual support or the faulty reasoning used to defend the dogma. We may conclude Jesus was no Aryan.

The imaginary creed and the dogma aim to establish that Jesus was not a Jew. What is largely unstated is the thinly veiled argument that is meant to break down the sympathy of individuals toward Jews. It may now be stated as follows:

If Jesus was a Jew, then Jews deserve the respect that other persons receive.

Jesus was not a Jew.

Therefore, Jews do not deserve to receive the respect shown to other persons.

\section{The Efficacy and Logic of the Case for an Aryan Jesus}

It would be a gross misstatement to suppose that the dogma made individuals killers. The more modest claim is that the dogma had some causal efficacy in the killing of Jews. The dogma is presented as one only of a series of sufficient and non-necessary conditions that would lead German citizens and others to murder Jews.

The Aryan Jesus dogma may have been the one last straw that would have prevented some individuals from killing Jews. To recognize the efficacy of the dogma is not to suggest that the dogma itself is credible. Within the thinly veiled argument that would justify the mistreatment of Jews, the dogma functions as a premise. With its reliance on an unsound premise to support an invalid argument form the argument proves to be doubly flawed. The underlying argument makes use of the fallacious form of a denial of the antecedent: If P, then Q; not P, therefore not Q. It may now be restated: If Jesus is a Jew, then Jews deserve to be treated with dignity. Jesus was an Aryan. Therefore, Jews do not deserve to be treated with respect.

First, the thinly veiled argument for the dogma fails, since it asserts a premise that is the product of circular reasoning, namely, that Jesus was an Aryan. Our examination of the dogma revealed that it was the product of ideology and circular reasoning rather than sound scholarship. Theologians declared that Jesus was not a Jew, since theologians asserted that Jesus was Aryan.

Second, the thinly veiled argument for the dogma fails, since it is an argument to deny the antecedent. Students of logic recognized this as a fallacious argument form. To arrive at the desired conclusion by means of the thinly veiled argument, scholars would have to deny the antecedent. Not only does the argument invoke an unsound premise, but it also uses an invalid argument form.

In what way does that suggest that a guiding ethical principle was undergoing a transformation in response to the dogma? One of the most changeable general moral principles of action is that of truth telling: One ought to tell the truth. To construct the case for the Aryan Jesus scholars abandoned their commitment to truth telling. Instead, they created parts of a case that would make plausible the notion that Jesus was not a Jew. 
Disseminating that information was one more step in desensitizing the general public to the mistreatment and killing of Jews.

The practical outcome of Nazi anti-Semitism was the transformation of the normative ethical command: Thou shalt not kill. Nazis came to believe killing Jews was both permissible and obligatory. From the vantage point of the 21st century, it seems incredible that Germans would mount a national campaign to eradicate Jews, since Jews were inextricably intertwined in the national and religious life of Germany. That some Jewish citizens were honored veterans of World War I was undeniable. That Jewish citizens contributed to the economy of Germany was undeniable. That the state sanctioned religion of Christianity owed its origin to the Abrahamic religion of Judaism likewise seems undeniable. However, the propaganda provided by the Nazis denied the social and religious value of Judaism, included in that propaganda was the case for the Aryan Jesus. To gain further insight into why and how the case for the Aryan Jesus developed this study has focused on the fallacious argumentation underlying the main claims of the Aryan Jesus dogma.

Upon hearing that the Aryan Jesus dogma causally contributed to the death of many Jews, one colleague asked if this author saw within this tale a moral failure of the academy. One may view the University of Jena as a moral collective. This state funded university in Germany failed to rise to fulfill its humanitarian duties to defend the rights of citizens to engage in free speech and thought. The policy of credentialing only doctoral candidates whose dissertations supported anti-Semitic conclusions was morally blameworthy. If the university had either upheld the right of dissertation candidates to express their opinions or the opportunity to dissent, then it would not be blameworthy for depriving individuals of free speech and thought. Instead this university intentionally promoted the Nazi agenda within the academy.

The German DS Church was likewise responsible for its embracing the Aryan Jesus dogma. Consistent with the dogma were the prohibitions found in the Aryan paragraph. If one regards the appointment to clerical positions as a discretionary matter, the state church could have defended its exclusion of non-Aryans from the clergy as a matter of preference. However, the deprivation of more basic rights such the sacrament of marriage may be viewed as uncharitable or non-virtuous behavior. To the extent that members and leaders of the German DS Church may have contributed directly to the violent mistreatment of Jews, they stand condemned.

Apart from its bells and whistles, propaganda aims to appeal to some of the most basic appetites and instincts of humanity. Often propaganda gives people reason to believe what they want to believe, though the reason it gives may be unfounded. It may build upon subtle but not sound reasoning. This should become evident when we examine the case for the Aryan Jesus dogma. Consider this simple material implication: If Jesus was a Jew, then Jews deserve respect. The case for the Aryan Jesus asserts that Jesus was not a Jew. Logically, the denial of the consequent that Jews deserve respect, does not follow from the denial of the antecedent, Jesus was not a Jew. Nonetheless, the Nazis expended great effort to convince the public that Jesus was not a Jew. 


\section{References}

Armstrong, K. (2004). Fields of blood: Religion and the history of violence (1st ed.). New York: Alfred A. Knopf.

Arnold, J. W. (1997). Jesus as an historical Jew. Judaism, 46(3), 375-380.

Bergen, D. L. (2016). War and genocide: A concise history of the holocaust (3rd ed.). New York: Rowman \& Littlefield.

Browning, C. R. (1993). Ordinary men: Reserve Police Battalion 101 and the final solution in Poland. New York: Harper Perennial.

Edersheim, A. (1971). The life and times of Jesus the Messiah. Michigan: William B. Eerdmans Publishing Company.

Ericksen, R. P., \& Heschel, S. (1999). Betrayal: German churches and the holocaust. Minneapolis, Minnesota: Fortress Press.

Haupt, P. (1919). The son of man. The Monist, 29(1), 125-133.

Haupt, P. (1920). The crib of Christ. The Monist, 30(1), 153-159.

Heschel, S. (2008). The Aryan Jesus: Christian theologians and the Bible in Nazi Germany. New Jersey: Princeton University Press.

Hockenos, M. D. (2004). A church divided: German Protestants confront the Nazi Past. Bloomington, Indiana: Indiana University Press.

International Bible Society. (1978). The holy Bible: New international version: Containing the Old Testament and the New Testament. New York: International Bible Society.

Kerr, C. M. (1939). Judas Iscariot. International Standard Bible Encyclopedia Online. Retrieved June 7, 2019, from https://www.internationalstandardbible.com/J/judas-iscariot.html

Levine, A. J. (2007). The misunderstood Jew: The church and the scandal of the Jewish Jesus. New York: Harper One, an Imprint of Harper Collins.

Munson, H. (2018). Christianity, anti-Semitism, and the holocaust. Religions, 9(1), 26.

Renan, E. (1910). The life of Jesus. Boston, Massachusetts: Boston, Little, Brown, and Company.

Shepherd, J. A. (1939). The Christ of the Gospels. Michigan: William B. Eerdmans Publishing Company.

Steigmann-Gall, R. (2003). The holy Reich: Nazi conceptions of Christianity, 1919-1945. New York: Cambridge University Press. 